\title{
Pirates, Merchants and Anarchists: Representations of International Business
}

\author{
Martin Parker \\ School of Management \\ University of Leicester \\ University Road \\ Leicester \\ LE1 7RH \\ m.parker@le.ac.uk
}

\begin{abstract}
This paper considers the relationship between historical and fictional accounts of piracy, and relates them to contemporary issues about the legitimacy of states and global business. I begin by showing how privateers were gradually distinguished into pirates and navies. At the same time, the pirate becomes a character in the popular imagination, a 'trickster' figure on the side of the people, and against authority. The second main section of the paper moves from 'history' to 'representation' and shows how the image of the pirate moved from a wild character on the edge of the world, to a stock cliché for Hollywood swashbucklers. I then investigate the legacy of radical histories and representations of piracy, focussing particularly on the idea of alternative organization on the ship and the pirate utopias on the land. The final section pulls together the historical figure, the stock character and the radical rogue in order to suggest that the pirate can mean what what we want him (or to her) to mean. Nonetheless, the biggest historical irony is that the golden age pirate emerges at the beginnings of international business, and is only wiped out when the state and the businessman strike an alliance that lasts to the present day.
\end{abstract}




\section{Keywords}

Pirates, privateers, state, fiction, law, outlaws

\section{'WARNING}

The copyright proprietor has licensed this DVD (including its soundtrack) for private home use only. All other rights are reserved. Any unauthorised copying, editing, exhibition, renting, lending, public performance, and/or broadcast of this DVD, or any part thereof, is strictly prohibited. This DVD is not be exported, resupplied or distributed by way of trade outside the EU without a proper licence from Buena Vista Home Entertainment.

(C) Disney'

Text from DVD case of Pirates of the Caribbean: Dead Man's Chest, 2006

'the sea was given by God, for the use of men, and is subject to dominion and property, as well as the land'

Judge Nicholas Trot Esq, at the 1718 trial of Stede Bonnet and his crew (in Lewis 2006: 169)

\section{Introduction}

Captain Jack Sparrow would probably raise a camp eyebrow at the anti-piracy warning copied above. He would, however, be impressed that the film has grossed well over one billion dollars. Its predecessor, Pirates of the Caribbean: The Curse of the Black Pearl (2003) only 
grossed $\$ 733$ million, beaten by the third film Pirates of the Caribbean: At World's End (2007) on nearly one billion. This is a total of \$2 680308 734, not including income from DVD rentals and sales, sponsoring tie-ups and merchandising. Neither does it include the versions of the films which are sold as pirate DVDs on markets all over the world, or streamed off the internet for private use, or shown illegally in small cinemas in many parts of the globe ${ }^{1}$. The money is important here, just as it always has been with pirates, and the antipiracy warning warns of a few other concepts that matter too. One is the legal idea of a license, an agreement from a properly constituted authority, and the other is territorial, simply because authorities tend to govern particular places, and not all places, all of the time. Indeed, it is precisely the spatial limits of authorities that constitute the pirate, and their cousins, buccaneers, corsairs and privateers. No wonder Judge Trot had to be so insistent about ownership of the sea.

Pirates make money for other people, not just themselves. The merchant in the port, the smuggler, the innkeeper, the governor who turns a blind eye, the monarch who accepts the tribute, and for the popularisers of pirate mythology as well. In 1724 Captain Charles Johnson (sometimes supposed to be Daniel Defoe) published the first volume of his General History of the Robberies and Murders of the Most Notorious Pyrates, and Also Their Policies, Discipline and Government (1998) The book, with its series of chapters on famous pirates, pretty much defined the symbolism and characterology of this economic outlaw and was a big success. It rapidly went through three editions (each more enlarged than the last), and a second volume - more fiction and disguised social criticism than serious history - followed in 1728. Since then, there have been seventy editions in four languages (Burl 2006: 265). Much of contemporary piratology comes from this book. Whether the wild eyed psychopaths, like Blackbeard or Edward Low, or the gentlemen robbers, like Captains Mission, Bellamy, Bonnet and Roberts, the pirate has become both celebrated and reviled. This is a typically 
ambivalent construction for a description of another way of living, as well as a set of social relations that both inverted and exceeded the cruelties of European imperialism.

This ambivalence shines through in writing about pirates. Whilst there are some who clearly celebrate the romantic outsiders (Rediker 2004, Snelders 2005, Woodard 2007 for example), the majority seem compelled to temper their remarks with episodic moralism. It is as if, suddenly finding themselves carried away, they have to remind us where they stand, just in case there was a misunderstanding. As Earle puts it 'the author of a book such as this one cannot be certain that all his readers will necessarily be on the side of law and order' (2004: xii). In this paper, I am on the side of the pirates, but largely in the sense that they provide a way of thinking about the boundaries of legitimacy for states and economies. However, I do not see this as a matter which can be restricted to 'historical fact', as if such an ephemeral court could be the judge of such claims. My motive for writing this paper was to account for the popularity of Captain Jack Sparrow by tracing representations of piracy. In doing so, I found that history and representation are too intertwined to be disentangled. Giles Lapouge (2004: 19) suggests something similar-

'If we want to penetrate the mysterious heart of the pirate adventure, we must therefore observe these evildoers in two lights at the same time - that of reality and that of dream. (...) The treasure chests of Henry Morgan and Rock the Brazilian are real - and this reality is imaginary.'

In other words, there is no 'truth' of piracy that is accessible to us, but 350 years of talking and writing about pirates has opened up some very interesting ways of thinking about the relation between the state, the merchant, and organized crime. Or, to put it another way, to ask why some forms of making money are legitimate, whilst others are not. It seems to me that Jack Sparrow holds this question in his raised eyebrow. 
The paper begins by showing how the flexible mercenaries called privateers were gradually distinguished into pirates and navies. This involved the forging of an alliance between the emerging mercantile classes and their companies, and the outlaw figure of the pirate. At the same time, the pirate becomes a character in the popular imagination, a 'trickster' figure on the side of the people, and against authority. The second main section of the paper moves from 'history' to 'representation' and shows how the image of the pirate moved from a wild character on the edge of the world, to a stock cliché for Hollywood swashbucklers. Following that, I investigate the legacy of radical histories and representations of piracy, focussing particularly on the idea of alternative organization on the ship and the pirate utopias on the land. The final section pulls together the historical figure, the stock character and the radical rogue in order to suggest that the pirate can mean what what we want him (or to her) to mean. Nonetheless, the biggest historical irony is that the golden age pirate emerges at the beginnings of international business, and is only wiped out when the state and the businessman strike an alliance that lasts to the present day. Selling Captain Jack necessarily opens the possibility that some other histories might get smuggled in too.

\section{Histories}

There was piracy before, and piracy afterwards, but this paper concentrates on Atlantic piracy in the $17^{\text {th }}$ and $18^{\text {th }}$ centuries. There is no good reason for this, other than that this is the mythological location for the 'golden age' of piracy, and the time when, in 1700 Captain Cranby of HMS Poole first saw the French pirate Emmanuel Wynne fighting under 'a sable ensign with crossbones, a Death's head and an hour glass' (in Lewis 2006: 228) ${ }^{2}$. There were pirates elsewhere at the same time, such as the largely Muslim Barbary Corsairs who attacked Christian ships in the Mediterranean, or the Knights of Malta who opposed them, or Asian and European pirates who took ships in the Indian Ocean. There are also predecessors to the 
golden era of piracy, such as the early $17^{\text {th }}$ century Buccaneers (boucaniers) based on Hispaniola who preyed on Spanish shipping and cities in the Caribbean, or the Dutch Sea Rovers or Freebooters (vrijbuiter) from the $16^{\text {th }}$ century. Or, we could go back to Cicero, in his 67 BCE account of Heracleo the pirate who plagued the coast of Sicily (in Lewis 2006: 22). Or forward to November $5^{\text {th }} 2005$, when the cruise ship 'Seabourn Spirit' was attached by rocket propelled grenades off the coast of Somalia. But this is not a history of piracy, but a genealogy of Captain Jack.

We can't really understand Jack without understanding something about the state particularly the Spanish, Portuguese, French and English states. During the early golden age, the device of 'privateering' effectively allowed for an extraordinarily powerful combination of mercenary politics and mercantilism. In Elizabethan England, all the maritime heroes spent some time as state licensed pirates - Hawkins, Grenville, Frobisher, Raleigh and others. A 'Letter of Marque and Reprisal' (both a legal device and an economic contract) specified the legitimacy of the targets, as well as the distribution of the spoils. Privateering was noble and profitable, Elizabeth referring to Sir Francis Drake as 'my dear pirate'. The device had the further advantage of relieving the monarch of the costs of maintaining a large standing navy, whilst the discipline was seen as an effective training ground for potential navy recruits (Earle 2004: 23). The merchants and gentlemen who financed a privateering trip usually expected two thirds of any profit, with the remainder being very unequally divided between the captain, officers and crew. But on a long sea voyage, what was a legitimate 'prize', and what counted as 'profit' were inevitably flexible. It was quite possible for a gentleman who had exceeded his instructions to be pardoned, and even given public office, as was the case with Henry Mainwaring in 1616 and Henry Morgan in 1675. For merchants, carrying a Letter of Marque was also a form of insurance which diversified the sources of possible profits from a voyage (Kontorovich 2004: 212). There was also, in places far from the centres of imperial power, a 
substantial amount of productive confusion about who was entitled to offer Letters of Marque and pardons. The governors of Jamaica or Tortuga, or the representatives of the trading companies, had some latitude in this regard, and could easily interpret directives to suit local circumstances. At the start of the golden age, it seems that the boundaries between legitimate and illegitimate violence, or profit and crime, were unclear.

But by the end of the period, the boundary is being enforced most violently. Burl describes the 1722 trial of Black Bart's crew at Cape Coast Castle on the Royal African Company's Guinea coast of West Africa.

'Behind a long table at one end of the chapel sat the judges, naval officers in their blue brass-buttoned uniforms, elegant, three-corner hated governors, powder-wigged, comfortably seated. Atkins, the registrar, was at a separate table, quills sharpened, inkwell filled, notepaper neatly arranged.

At the far end of the hall were the pirates. Guarded by scarlet coated soldiers the men were in rags, filthy from the dungeons, fetters clattering as they shuffled in, unshaven, unwashed, all reeking with dirt, unrecognisable from their days of silken glory.' (2006:

They may have been unrepentant, and 'walk'd to the Gallows without a Tear' (Rediker 2004: 12), but the alliance between mercantile capital and the state was now evident. Pirates were now an obstacle to commerce, and hence needed to become hostis humani generis - common enemies of mankind.

The interests of the trading companies were key here. The French West India Company, the Dutch East India Company, the Royal African Company and many others were initially small investment gambles on a ship and a captain. But they grew to become determinants and instruments of state policy. In England, Earle claims, it is not until the end of the $17^{\text {th }}$ century 
that an alliance between the mercantile classes, state bureaucrats and aristocracy effectively committed them to creating the conditions for the expansion of both trade and the empire. 'The state would provide protection for trade and, in return, would receive a flow of revenue from increased wealth and customs duties and a pool of trained sailors to fight in its naval wars. There was to be no place for pirates in this new world, no place for individualist marauders on the periphery of empire.' (2004: 146)

Corrupt governors were removed, laws were revised and more ships were sent on station to areas where there was a pirate menace. There was even an attempt to present merchants, seen by common people as greedy and duplicitous, as 'most Useful and Beneficial to the Publick' and possessed of 'indefatigable Industry' that nourishes every member of the 'Body Politick' (Rediker 2004: 134). In legal terms, piracy now becomes the benchmark for crimes so heinous that they fall within an universal jurisdiction, and are hence not even subject to the vagaries of state law. A pirate can be detained or killed by anyone, in any part of the globe and the analogy is even now a central metaphor for claims about the universality of international law, and the protection of international trade (Kontorovich 2004: 230)

But whatever was being pronounced in London or Madrid concerning the barbarities of pirates, there were plenty of people, rich and poor, home and abroad, who were still very happy to support them. Wealthy landowners effectively taxed piracy as a source of income, and also used pirates to oppress and plunder their tenants (Earle 2004: 20). Merchants, shopkeepers and traders profited, and ordinary people benefited from access to cheap goods. Indeed, it seems that many were attracted to 'go on the account' precisely because of the popular notoriety of the pirate. Henry Avery, the first mentioned in Johnson's General History, is described as a 'maritime Robin Hood' and ballads and broadsheets celebrated the bravery and liberty of those who robbed the rich (Rediker 2004: 173). Pirates had already become semi-mythical figures, playing both inspirational and cautionary roles in a variety of 
contexts. Land sums this up by suggesting that 'even in their own time the pirates were perceived as politically dissident, revolutionary figures and popular accounts of their utopian communities offered a biting tool for the political critic and satirist to attack the hypocrisy and corruption of Church and State.' (2007: 180)

Lapouge suggests that pirates 'developed their project of escaping from history under the protection of history - and they could obviously perpetrate their atrocities more easily in a turbulent world than in a peaceful one. They thrived in the cracks that ran through states.' (2004: 90-1). These cracks were also cracks in representation, from the bloodthirsty sociopath, to the smiling rogue, and it is to these representations that I now turn.

\section{Representations}

Accounts of seafaring robbers are common enough in classical literature. Ancient myth, and the writings of Homer, Herodotus, Thucydides, Plautus and Terence provide plenty of accounts of plunder, raids, kidnap and so on. These are either routine acts of state approved terrorism, or people trying to make a living from foreigners and slavery. Roman literature rather predictably makes pirates into criminals, whilst later mediaeval tales suggest pirates as fantastical, and perhaps possessed of magical powers. Alwilda the Dane was said to have a largely female crew; Eustace the Black Monk privateered for England and France in the $13^{\text {th }}$ century and could make his ship invisible; and Johan Stortebecher the German privateer had a hollow mast filled with gold (Rogozinski 1997: 122). But it is not until the beginning of the $18^{\text {th }}$ century that a particular condensation of images emerges which largely endures to the present day. 
In 1719, Daniel Defoe published Robinson Crusoe. Apart from the native 'Friday', Crusoe is shipwrecked alone on the island, and is largely occupied with re-creating the civilisation he has left behind. Though there are many different readings of the novel, the majority would focus on Crusoe's conquest of nature, and his construction of a small scale Arcadian version of paradise. Defoe may well have been influenced by Henry Neville's 1668 'pornotopia' Isle of Pines (Bruce 1999), but in its turn the influence of Defoe's book was huge, producing an entire sub-genre of 'Robinsonnades' in the following two centuries. Some were largely derivative versions of industrious Europeans surviving in various forms of wilderness, often accompanied by homilies on simplicity and hard work, such as Johann Wyss's Swiss Family Robinson (1813). Others, with more radical intent, began to develop the romantic idea of the 'noble savage' and the original state of nature which fitted so neatly with accounts of Eden and the idea of a golden age, and which had been prefigured in de Foigny's New Discovery of Terra Incognita Australis (1676). Books such as Swift's Gulliver's Travels (1726), and Diderot's Supplement to Bougainville's Voyage (1796) contained ideas about travel to 'virgin' islands where people and creatures were found who showed the manners, politics and institutions of Europe in a distinctly negative light. They were closer to simplicity than their conquerors, like innocent children who ask the most awkward (and revealing) questions.

Rousseau's suggestion that the education of his pupil in Emile (1762) should proceed through a reading of Robinson Crusoe (in preference to the classical education assumed at the time) underlined the idea of 'natural man' being born free, but everywhere placed in chains. But Robinson Crusoe was not entirely fictional. In 1704, a Scotsman called Alexander Selkirk had been marooned for over four years on Màs-a-Tierra, in the Juan Fernandez Islands off the coast of Chile. He was rescued by a privateer, Captain Woodes Rogers, in 1709, later the author of A Cruising Voyage Round the World (1712, see Lewis 2006: 157), which Defoe read. So the author of the General History, published five years after Crusoe, could easily 
have been Defoe, or could have been the Charles Johnson who wrote the play The Successful Pyrate first performed in 1712. It could also have been some author of other accounts of piracy now attributed to Defoe, such as The King of the Pirates (also 1719), The Life, Adventures and Piracies of Captain Singleton (1720), Colonel Jacque (1723), A New Voyage Round the World (1724), and The Four Years Voyages of Captain George Roberts (1726). The mystery seems appropriate, and entirely consonant with others who have written of strange lands, and even utopias ${ }^{3}$.

As is common in such accounts, the fiction becomes the fact. Màs-a-Tierra was renamed Isla Robinson Crusoe, and 'Captain Johnson' became the inspiration for a thousand books and films. Not that The General History is the first pirate book. Alexander Exquemelin's The American Sea-Rovers was published in Dutch in 1678 and is both a travel book and an account of the extraordinary cruelty and violence of the buccaneers. Exquemelin tells us about jungle people with claws like monkeys that allow them to climb trees, descrbes prisoners being hung by their genitals or gradually hacked to death, and 'spiders with a body as big as an egg' (2000: 97, 151, 45). Within eight years the book had been translated into five languages ${ }^{4}$. William Dampier's New Voyage Round the World (1697) covered similar territory, became a best seller and brought him some fame as a naturalist. After publishing his follow up, A Voyage to New Holland (1703) Dampier and another ship, the Cinque Ports, went on a privateering voyage to South America. The ships parted in Panama in 1704, and after the death of its Captain and a series of arguments, it was the Cinque Ports that marooned Alexander Selkirk. On a later voyage Dampier was accompanying Captain Woodes Rogers when he rescued Selkirk (Rogozinski 1997). So stories of amazing animals, the odd customs of native people and accounts of robbery bring together elements of travel journalism and diaries, science and utopian literature. But (after something of a silence in the second half of the $18^{\text {th }}$ century), the re-reading and writing of the General History throughout the $19^{\text {th }}$ 
century largely erased these variegated origins, and begins to construct an archetype of setting, imagery and behaviour which could be re-presented in some highly profitable ways. In part, this involved the creation of the historical romance, particularly the novel, as a vehicle for popularising the pirate

The first 'fictional' pirate is probably Arviragus in Charles Johnson's play The Successful Pirate (1712), though even he is probably a disguised version of Henry Avery, later also to appear in Captain Johnson's work, though there is probably no relation between the two Johnsons. There is little else in fiction until James Cross's play Blackbeard; or, the Captive Princess ('a serio-comic ballet of action, in two parts') was presented in 1798 (Cordingly 1999: 233). This play was revived continually during the $19^{\text {th }}$ century, but it is Byron's poem The Corsair (1814) that was perhaps the first really influential fictional account of the loneliness and mystery of the pirate, an ambiguity which allowed the character to be potentially both villainous and noble. It sold 10000 copies on its first day of publication, and installed the pirate as a Byronic hero, though in this case an 'oriental' not a Caribbean pirate. Supposedly inspired by Jean Lafitte, a French privateer who fought the English at the battle of New Orleans, Byron's Conrad was 'Lone, wild, and strange, he stood alike exempt/ From all affection and from all contempt.' The title of the poem was borrowed for Berlioz's overture of 1844, Verdi's opera of 1848, and Adolph Adam's ballet of 1856 (revived and revised in various versions). Walter Scott (widely acknowledged as the inventor of the historical novel) published The Pirate in 1822, Edward Fitzball wrote the play The Red Rover, or the Mutiny of the Dolphin in 1829, and Charles Ellms partially plagiarised Defoe for his Pirates Own Book in 1837 , with at least nine subsequent editions. By the mid $19^{\text {th }}$ century the pirate begins to become a stock character in fiction with stories by Captain Marryat, Charles Kingsley, Washington Irving, James Fenimore Cooper, Edgar Allen Poe, Robert M Ballantyne and other less known authors, as well as Gilbert and Sullivan's 1879 operetta The Pirates of Penzance. 
Robert Louis Stevenson's Treasure Island of 1883 is hence, despite its supposed seminality, quite a late work, and one that borrowed heavily from The General History, as well as the authors mentioned above. J.M. Barrie's 1904 play Peter Plan became a book in 1911, and the contemporaneous fiction of Howard Pyle, Samuel Walkey and the later novels of Rafael Sabatini then begins to provide plots for films, as well as articulating a version of the evil Spaniard, and the noble born or honest pirate. In a century, the pirate had moved from Byron's romantic and dangerous icon, to children's book cliché and bare-chested swashbuckler.

These, rather de-politicised, images then go on to define pirates in $20^{\text {th }}$ century film. Parish could summarise the plots of 137 pirate films in 1995, and characterise them as 'a man fighting for the right in a world that does not understand the right as he sees it' (1995: 3). The novels of Sabatini were adapted for films with Douglas Fairbanks senior and junior, Errol Flynn, Tyrone Power and others. Part of a wider genre of swashbuckling films, sword play and bare chests are pitted against evil pirates or evil Spaniards in Captain Blood (1926), The Sea Hawk (1940), Captain Kidd (1945) and so on. There was something unthreatening about many of these films, with good and evil being so clearly marked. The reviewer of The Black Pirate of 1926 in the New York Times puts it well. 'This is a production which marks another forward stride for the screen, one that the boy and his mother will enjoy and one that is a healthy entertainment for men of all ages.' (in Cordingly 1999: 203). Many of these films required that the wholesomeness of the pirate was maintained by having him be a outlaw aristocrat, or falsely accused of a crime, or disguising himself for the purpose of vengeance, or simply a privateer for England and the Queen. Richards suggests that the core of these films is 'male beauty' and 'a joyous love of adventure' 'The values are the values of the knightly class, as embodied in the chivalric code' (1977: 4) The object of the hero is not revolution, but restoration, or the extermination of general evil such as slavery, or a specific 
pirate or governor. These films do not endorse piracy, or spend much time presenting the social relations that created the pirate.

'Even when the heroes are unequivocally pirates, they are not criminals. They are rebels with a cause, the fulfilment of which leads to their retirement. They seek revenge for a father/mother/brother or they campaign against slavery and oppression or, most often, they represent the forces of truth and justice against the universal enemy, Spain, opponent of liberty, overlord of slavery, grim graveyard of freedom.' (Richards 1977: 268)

By the second half of the twentieth century, even the thin politics of the swashbuckler is beginning to fade, and the pirate film begins to become a vehicle for the children's romance or the comedy pastiche. Abbot and Costello meet Captain Kidd (1952), Yellowbeard (1983), with many of the Monty Python team, and Hook (1991) become fairly representative of the limits of the genre, with the occasional attempt to bring a little sword-play back in with films such as Pirates (1996). To a certain extent, Jack Sparrow inherits this set of marketing clichés, as well as this target market. We seem to have moved a long way from the idea of the pirate as a revolutionary figure, as a character who problematises the state monopoly over violence for political and commercial gain. But there are other histories of representation that can be told too, and perhaps Jack still contains faint echoes of these other ways of being.

\section{Alternative Organization}

Navy and merchant ships were vicious and insanitary places. Naval discipline was cruel and violent, with officers often demonstrating sadistic cruelties in support of discipline. Moreover, the food was bad and the pay poor. These conditions of labour, combined with continual mortality, meant that ordinary seaman were often 'pressed' into service, either from British or 
foreign ports. Such a recruitment policy was necessary simply because one in four of the crew on a slaving ship would die on the voyage (Earle 2004: 167). Land quotes a series of figures that could be summarised by suggesting that if half a crew returned the ship had done rather well (2007: 174). If this was 'normal' seafaring work, then the life of a pirate must have seemed like such an attractive option. Indeed, the abuse suffered under normal regimes is often cited as a mitigating factor for piracy during trials and confessions (Rediker 2004: 4). But pirates also developed radical alternative forms of work and economy, and it is easy to imagine the stories concerning the proto-democratic and egalitarian practices circulating on board navy and merchant ships. These became central to early representations of piracy.

It is with the buccaneers that we first begin to see stories about the emergence of a radical collective identity. This was a community of exiles who developed the 'custom of the coast', the 'Jamaica Discipline', or the 'Law of the Privateers'. Nicknames replaced birth names, and it was forbidden to speak of a man's origins (Earle 2004: 101). Many historians have suggested that there was a real radicalism here, a class hostility combined with a peasant utopianism that constructed an image of a 'revolutionary Atlantic'. This, in part, was driven by a brutalised experience of labour, but also by currents of political radicalism inherited from the English Revolution. Members of the New Model Army, Ranters, Diggers, Levellers and radical Protestants provided a political rationale for an anti-authoritarian politics (Hill 1986, Lamborne Wilson 1995: 20, Linebaugh and Rediker 2000, Rediker 2004: 61 passim, Parker et al 2007). Adding to this political undercurrent were slave rebellions which happened throughout the $17^{\text {th }}$ century, as well as uprisings of indentured white servants (Do or Die 1999). On board the ship, the influence of the increasing numbers of ex-merchant seaman is important as 'pirate ideology now began to reflect the grievances of the lower deck as well as the ideals of the buccaneers' (Earle 2004: 166). It may well also reflect the socially isolated yet collective and synchronized experience of seafaring labour (Linebaugh and Rediker 2000, 
Rediker 2004: 25). These contexts set the scene for the political economy and organization of piracy during the early $18^{\text {th }}$ century.

'Articles' were a form of social contract, a collectively agreed description of the boundaries of legitimate authority. They were used by buccaneers (see Exquemelin 2000: 71), but become more fully developed with the pirates of the golden age. Those drawn up by Captain Roberts were similar to those of Captains Lowther and Philips, so we can assume that their substance was transferred between pirate ships, with amendments to cope with the desires of particular Captains and crews. Roberts' eleven articles gave each man a vote, most an equal share of stores and plunder, and rewards for being one of the boarding party on a prize. The few who benefited unequally were the Captain and Quartermaster (two shares each), the Master, Boatswain and Gunner (one and a half shares each), and other officers (one and a quarter). In comparison with the unequal shares and wages on merchant and navy vessels, this was remarkably egalitarian, but this didn't mean that the boat was free from violent authority. Punishments were to be enforced for theft, desertion, or fighting on board, and there was to be no gaming for money. Lights were to be put out by eight o'clock, and drinking could be continued only on deck. All pirates were to keep their pistols and swords clean, and no boys or women were allowed on the ship. Compensation for injury was established, depending on the severity of the injury, and any musicians were allowed Sunday off (Burl 2006: 103-112).

This is a remarkable list. It contains both considerable rewards, and a graded set of punishments - being set ashore somewhere where hardships would ensue, slitting the nose and ears, a slow death by marooning on an island, or a quick death on board. The details of different articles are interesting, but they are all unified by the absolutely radical idea that authority depended on consent. Articles were usually sworn on a bible, though Captain Philips used an axe, and consent was signed or marked on the articles themselves, and solemnised by 
heavy drinking. Importantly, the captains themselves were also voted for, often with the advice of the 'lords', the senior members of the crew. Charles Ellms quotes one lord addressing the others on the election of Captain Roberts in 1719.

'... the good of the whole, and the maintenance of order, demanded a head, but that the proper authority was deposited in the community at large; so that if one should be elected who did not act and govern for the general good, he could be deposed, and another be substituted in his place.' (in Lewis 2006: 230)

The Captain only had absolute authority during conflict. At all other times, he was subject to consent, even over the use of his cabin, and his manners, which were not supposed to be too 'Gentleman-like' (Rediker 2004: 65)

But pirates were not simply inhabitants of separated floating polities. Rediker (1987) argues that the connections between crews and boats were strong during this period, and that there was a certain co-operation between ships, which sometimes operated collectively. The epitome of such co-operation is the idea of the proto-democratic community moving onto the land. This is not an idea that was restricted to the golden age, or the Caribbean. Accounts of cities such as Rabat-Salé on the Atlantic coast of what is now Morocco (Earle 2004: 44) suggest a self governing and multi-national city-state which was economically reliant on piracy and slavery. Lamborne Wilson's book on the Sallee Rovers pays particular attention to the 'renegadoes', Christians turned Muslim, and pirate (1995). Though the mercantile relationships in Algiers, Tunis and Tripoli were better described as small business capitalism, the Corsair captains enjoyed a summer of piracy and a winter of entertainment, seemingly rather untroubled by the nominally Islamic nature of the city. In Salé, the division of the spoils was much more communistic, and the regulation of behaviour was anarchistic, leading Lamborne Wilson to conclude that, though not a pure pirate utopia, 'it was the only state ever founded on these principles' (1995: 146). 
If not founded on radical principles, there were certainly other pirate towns. Places like Tortuga off the north west coast of Hispaniola (now Haiti and Dominica); New Providence in the Bahamas (now Nassau, see Woodard 2007); and St Mary's (Saint-Marie) off the northeast coast of Madagascar might be described as pirate republics, but were probably better imagined as frontier towns. In 1891, Howard Pyle described Tortuga as 'a center of inflammation, a burning fire of human wickedness and ruthlessness and lust' (in Lewis 2006: 26). According to Defoe, Captain Avery The King of the Pirates (1719) settled for a while on Madagascar, as the mock king of a libertarian settlement. A Captain North also established a temporary settlement in Madagascar (Lamborne Wilson 1995: 193), and John Plantain claimed to have established a settlement at Ranter Bay, on the same island in about 1720. The 'King of Ranter Bay' is often enough referred to as Ranters' Bay, though there is no evidence of any connection to the mid $17^{\text {th }}$ century English radicals.

However, the most inspiring pirate utopia is probably a fictional one. In the fourth edition of the General History we can find an account (probably fictional) of 'Libertalia' ${ }^{6}$, supposedly established by Captain Mission and claimed by Johnson to be translated from a French work. Mission's community was inspired by the radical (and defrocked) Dominican monk Carracioli who was intent on remaking Eden in the Bay of Diego-Suarez, again in Madagacascar. Libertalia was based on equality of ownership, a democracy that only elects councillors for three months at a time, and Mission himself was elected 'Lord Conservator' for three years. Money was put in a common chest, there were no hedges between fields, property was distributed to all, and the slaves on captured vessels were freed. All decisions were to be the subject of a general vote by the 'Liberi', there was no death penalty and complete religious tolerance. Johnson, in thoroughly utopian style, has Mission say that he has not 'asserted his own liberty to enslave others'. All races mingled freely, there was an attempt to construct a 
common language and, at the beginning, an attempt to impose chastity. This gave way to polygamy. It lasted for a few years, with up to 400 inhabitants. (Earle 2004: 129 passim; Lamborne Wilson 1995: 193 passim; Lapouge 2004: 131-38). Lamborne Wilson insists that there is no reason to suppose that Libertalia did not exist, and many reasons to think that it might have done. William Burroughs was so impressed with Captain Mission that he proposed him as an example for the dispossessed of the world. Mission's was a 'retroactive utopia', a moment when history could have been different, and a world of communes could have opened 'freedom from the tyranny of government' 'Your right to live where you want, with companions of your choosing, under laws which you agree, died in the eighteenth century with Captain Mission' (1999: 416).

The question of who those companions might be is also important to Captain Johnson, though perhaps his concerns were more to do with marketing his book.. In the first edition of the General History there was a fold out picture of Anne Bonney and Mary Read, the most famous female pirates. According to the narrative, Bonney was born illegitimate and raised as a boy. She joined Calico Jack Rackham's crew in the Caribbean where she met Mary Read. Read was also illegitimate, and was dressed as a boy by her mother. She disguised herself as a man and fought in Flanders and the Netherlands, eventually joining pirates in the West Indies. Famously, she fought a duel over her male lover, and killed the man who had challenged him. The accounts of Bonney and Read now play centre stage in a wider story of women, violence and the sea. The two pirate women are inserted into a history that stretches back to Queen Artemesia from the Persian Gulf in 480 BCE, Queen Teata from the Adriatic in the $3^{\text {rd }}$ century BCE, the legendary Alfhild or Alwilda the Terrible in $9^{\text {th }}$ century Scandinavia, and Jeanne de Belleville from Nantes in the mid $14^{\text {th }}$ century. As with stories of men's release from wage slavery, the stories of female pirates tell of escapes from subordination to a gender role. Icons include Grace O’Malley and Elizabeth Killigrew, both from Ireland in the 1560s, 
as well as the $16^{\text {th }}$ century Englishwoman Charlotte de Berry, who led a mutiny and became Captain Charlotte. Mary Harley and Mary Crickett were from Virginia in the early $18^{\text {th }}$ century, and the English Ann Mills cut the head off a Frenchman, after running him through with a sword to ensure that he was dead. Maria Cobham was a Plymouth prostitute who married and went to sea with Captain Thomas Cobham. Mary Ann Talbot dressed in men's clothing at the compulsion of her 'guardian' Captain Essex Bowen, and Hannah Snell ran away to sea in search of her husband. (Do or Die 1997, Lapouge 2004: 158 passim, Burl 2006: 108, Rediker 2004: 113).

The idea of the female pirate marked $20^{\text {th }}$ century fiction too. In Fryniwyd Tennyson Jesse' Moonraker (1927) the handsome, fearless and tortured Captain Lovel turns out to be a woman with some strong opinions about female liberty. Women were sometimes seduced by the dashing pirate, such as Joan Fontaine in the film Frenchman's Creek (1944), but could also be beautiful and mysterious pirates themselves, such as Jean Peters in Anne of the Indies (1951), or Geena Davis in Cutthroat Island (1995). Jo Stanley's edited collection Bold in her Breeches (1996) brings together essays which insist that the sea was a place of relative freedom and tolerance for women who wished to live differently, and begins to construct the pirate as a feminist icon, as well as anarchist one. However, the 'truth' of such depictions is simply unavailable, and even those with radical sympathies have to acknowledge that women were more often objects of violence and superstition (Rediker 2004: 110).

But the radicalisation of pirate imagery doesn't end there. Barry Burg's Sodomy and the Pirate Tradition (1985) marks a current of writing that suggests a libertarian attitude to sexuality on board ship. Inducing from various pieces of evidence, Burg and others suggest that homosexuality, particularly in the form of junior companions, was common (Earle 2004: 107). Lamborne Wilson (1995: 185) simply notes, citing Foucault, that a specific form of 
sexuality between men, or men and boys, was not named at that point, and hence that there is a danger in importing $19^{\text {th }}$ century categories to an earlier context. Polymorphous sexualities may have simply been routine, and it is this sense of libertarian sexual tolerance and a certain kind of dandyism that also gets celebrated by William Burroughs in his writings about the city of Tangier, and the accounts of Captain Mission and the Cities of the Red Night (Burroughs 1999). Hardly surprisingly, added to this sexual diversity is the idea that pirate ships were racially heterogeneous too. One source suggests that $30 \%$ of pirate crews were of African descent, though Earle believes this to be something of an exaggeration (2004: 171). Cordingly records a series of examples of black seaman on pirate ships, but notes that they were probably used as slaves (1999: 27). Rediker is much more optimistic, recording examples of 'free negroes' (2004: 54 passim). Partly supporting such descriptions is evidence about the national origins of pirate crew. Black Sam Bellamy's crew of 1717 included British, French, Dutch, Spanish, Swedish, Native American, African American and African sailors (Rediker 2004: 53).

Whether Captain Jack Sparrow can bear the weight of such representations is questionable, but they reveal an account of piracy which attempts to both connect the pirate to $17^{\text {th }}$ and $18^{\text {th }}$ century radicalism, and also to make them reflect $21^{\mathrm{h}}$ century concerns. Jack may be a rogue, but he dresses well, and is not (at heart) racist or homophobic, and his sexism is of such a transparent form that it is difficult to take seriously. In the radical imagination, the pirate crew, male and female, straight and gay, black and white, is re-cast as a democratic assembly of equals. Pirate scholarship over the past forty years seems to have made them revolutionaries in their constitutions and practices, a model of alternative organizing and identity that can be projected into a romantic past, in order to inspire a different future.

\section{Freedom, and the Radical Imagination}


'In an honest service there is thin commons, low wages and hard labour. In this, plenty and satiety, pleasure and ease, liberty and power. And who would not balance creditor on this side, when all the hazard that is run for it, at worst, is only a sour look or two at choking? No, a merry life and a short one shall be my motto.

Damnation to him who ever lived to wear a halter.'

(Black Bart Roberts, 1670? - 1722, in Burl 2006: vii)

Roberts wore fine clothes, drunk only tea from fine china, and enjoyed listening to pressed musicians. His ship sometimes fired 'a miscellany of smallshot, pellets, broken bottles and nails' that could 'ravish a living body into a carcass of disentangulated flesh and scarecrowed bone' (Burl 2006: 130, 163). The pornography of violence sits alongside the demand for freedom. The violence and sadism of pirates is well documented (Cordingly 1999: 3, 157), but so are the cruelties of merchant and navy captains (Rediker 1987,2004), as well as the legal and ecclesiastical systems at home and in the colonies. Drowning, pressing, burning, hanging and strangling were all legitimate death penalties, not to mention the tortures applied by various inquisitions. So perhaps the violence can be set aside as historical context, and the sort of decoration that many readers (and writers) enjoy. Pirates were not unique, or even unusual, in being cruel to their enemies, but the violence certainly helped authors, from Exquemelin onwards, to sell images of piracy.

Not just pirates though. In 1734 Captain Johnson published A General History of the Lives and Adventures of the most famous Highwaymen, Murderers, Street Robbers, \&c. to which is added a genuine account of the Voyages and Plunders of the most notorious Pyrates. The pirate seems to be one historical figure amongst many that implicitly problematise the relation between crime and work. Whether highwaymen or the sparking rogues of endless heist 
movies, audiences have continued to enjoy tales of Robin Hood, Bonnie and Clyde, the Mafia, Western outlaws, Dillinger, smugglers and so on (Parker 2008). All, like Captain Jack Sparrow, can be read as characters that dramatise the contrasts between our lives of constrained labour, and open the possibility of alternative forms of organization and exchange.

So from Captain Johnson onwards, the pirate combined a swaggering marketability with a sense of political danger too. The character seems to embody many contradictions in terms of the organization of work and the distribution of reward, and to occupy a historical moment when the legitimacy of states, merchants and international trade was not yet fully established. This gap, this power vacuum, even today provides for the possibility of imagining freedoms beyond those that market managerialism allows, and perhaps even forms of re-distribution that erase hierarchies of status and reward. According to one of their prisoners, the pirates Bellamy and Lebour 'pretended to be Robbin Hood's men'. Captain Johnson, in one of the later and probably more fictionalised editions of his work, suggests a speech for Bellamy to the captain of a captured navy ship.

'damn ye, you are a sneaking Puppy, and so are all those who will submit to be governed by Laws which rich Men have made for their own Security, for the cowardly Whelps have not the Courage otherwise to defend what they get by their Knavery, but damn ye altogether: Damn them for a Pack of crafty Rascals, and you, who serve them, for a Parcel of hen-hearted Numskuls. They vilify us, the Scoundrels do, when there is only this Difference, they rob the Poor under the Cover of Law, forsooth, and we plunder the Rich under the Protection of our own Courage.' (Rediker 2004: 116)

No wonder that so many contemporary radical scholars could use the pirate to raise questions of legitimacy, particularly in a context when the trading companies that precede the global 
businesses of the present day can so easily be exposed as instruments of greed, class interest, and naked imperial power. The pirates' interest was not primarily wealth, because 'Pirates did not hide wealth. They wasted it.' (Burl 2006: 239) They drunk, they destroyed, they ate - they created a carnival which was entirely excessive in terms of an emerging culture of time is money, and returns on investment. In so doing, in denying the legitimacy of property, and dominion over the seas, they 'declared War against all the World'. This, to restate, was a world in which states and merchants were closing all the gaps, and demanding that their legitimacy was recognised through the use of violence too. If the sea had been a global commons, it was now subject to enclosure on behalf of states, in turn acting on behalf of an emerging capitalist class. But pirates had no country because they came 'from the seas' (Rediker 2004: 8, 72). For the 'authorities' this meant that pirates, like beasts, were a wild part of nature, separated from culture. This claim attempted to combat the notion that piracy was actually an alternative form of organizing, one based on face-to-face legitimacy and the satisfaction of immediate needs.

The trial of Black Bart's crew in 1722 that acted as the beginning of the end of the golden age of piracy was a symbolic defeat for a certain sort of organization, and a clear victory for another. John Atkins, the surgeon on The Swallow, the navy ship that had killed Bart himself, summarised one view of the matter rather nicely.

'Discipline is an excellent path to victory; and courage, like a trade, is gained by an apprenticeship, when strictly kept up to rules and exercise. The pirates though singly fellows of courage, yet wanting such a tie of order and some director to unite that force, were a contemptible enemy. They neither killed nor wounded a man in the taking; which ever must be the fate of such a rabble.' (Earle 2004: 198)

Discipline, in this context, merely suggests that autocratic and bureaucratic organizational forms might be more effective in the context of battle. But there is a further dimension to the 
condemnation of piracy, because if this was merely a choice between organizing principles, it could be deemed a contingent matter than any human being might make a choice about. So it had also to be a question of morality. Judge Trot, in his speech that pronounced a death sentence on Major Stede Bonnet, a gentleman pirate in 1718.

'... the Principles of Religion that had been instilled into you by your Education, have been at least corrupted, if not entirely defaced, by the Scepticism and Infidelity of this wicked Age; and that what time you allow'd for Study, was rather apply'd to the Polite Literature, \& the vain Philosophy of the times, than a serious Search after Law \& Will of God, as revealed unto us in the Holy Scriptures...' (in Lewis 2006: 174)

The will of God was on the side of law, and the state, and the East India Company.

Between 1716 and 1726 something like 500-600 pirates were hanged. The last pirate captain of the golden age, Olivier La Buse, was hanged on the beach on the island of Bourbon in July 1730 'before a cheering crowd' (Earle 2004: 206). But this doesn't mean that piracy is now merely a historical matter, indeed, it is still rather common. According to the International Maritime Bureau's 'Piracy Reporting Centre' in Kuala Lumpur, in 2006 there were 239 reported attacks. The most dangerous waters are those around Indonesia, with Nigeria, Somalia and Bangladesh having dangerous coasts too. There is also a growing literature on the problem, with quite a few books providing advice for smaller boat owners, and articulating the sea as a continuing site for dangerous outlaws (Burnett 2003, Hympendahl 2003, Langewiesche 2006). Larger attacks are sometimes mounted on cargo ships and cruise liners, using machine guns and rocket propelled grenades from small boats.

Neither should we assume that the link between the state and profitable violence is broken. This may be a golden age for the new privateers - mercenaries, security services and private armies. The US is at the forefront of privatising contemporary war to companies such as 
Blackwater, Brown and Root, Triple Canopy, Military Professional Resources Inc and so on (Chwastiak 2007, Armstrong 2008). The implications for foreign policy would be easily recognisable to Elizabeth the $1^{\text {st }}$, whilst the rape and plunder would be recognisable to Drake. Kontorovich (2004), in his commentary on the universality of piracy as a heinous offence, nicely shows how privateering and piracy have always been porous categories. The 'licensed privateer' principle brings into doubt the 'common enemies of mankind' principle, which suggests that neither are actually principles at all, but depend on which way the money is moving. In other words, moralising about pirates has a long pedigree, but so does putting a certain distance between the state and the mercenary.

So the money is important, just as it always has been with pirates. Other people have made a lot of money by employing them, by condemning them, and by re-presenting them. Osborne (1998) recounts how the North Carolina Maritime Museum was planning a new multimillion dollar exhibition on piracy after the discovery of the wreck of Blackbeard's Queen Anne's Revenge off the coast in 1996. He noted that 'politicians ecstatically foresee Blackbeard motels and restaurants sprouting up like mushrooms, and a mock cannon battle known as Blackbeard's Bounty Festival has been staged'. Captain Jack Sparrow has made his way onto lunch boxes, and Captain Charles Johnson's book has rarely been out of print for almost 300 years. As with Robin Hood et al, capitalism markets what it can sell. The irony is that, rather often, it ends up selling things which have histories that can easily be turned to other purposes.

Chris Land, writing about the links between piracy and anarchism, is well aware that pirates can mean different things. On the one hand, he suggests that Jack Sparrow is 'the embodiment of liberated, post-modern subjectivity, ruled by his desires and completely at odds with the staid world of work and civilization' (2007: 170). So perhaps he is merely an escapist figure, 
a character from a fantasy sold to us by the marketers running the dream factory. Yet, Land also wants Jack et al to mean more than this. Perhaps, he hopes, the "popularity of all things piratical may speak to something enduring in the popular imaginary: a desire for freedom and democracy (...) an insurrectionary current to the present day' (183). The skull and crossbones appears as a revolutionary symbol in the Paris Commune, and now unites anarchists and those who embrace the piracy of intellectual property in the name of the virtual commons. It seems to me that the very strength of images of piracy has been these entanglements of history and fantasy. From Exquemelin onwards, an utopia which resembles a state of nature has been articulated against the emergence of the venal mercantile state. An aquatic or island Arcadia, populated by authentic characters, is contrasted with the hypocrisies of self-righteous imperialism.

It might be said that this is 'bad' history, because it clearly confuses the 'reality' of piracy with the stories of Captain Johnson. But, as I think I have shown, these confusions go back to the earliest accounts. I think that, like Land, this means that 'perhaps we should be wary of over privileging the economic and 'real' history? In the creation of a moral economy and a distinctly radical culture, the pirates' political legacy has been long lasting and has made a significant contribution to the development of the contemporary culture of radical, anticapitalist and anarchist dissent.' (Land 2007: 190) I agree, but I would add that he has made a lot of money for Disney too. The point is that the 'pirate is malleable and plastic: villain, rebel, seducer, barbarian, man of the people, idealist, and sadist. He is what we want him to be.' (Osborne 1998).

Just as piracy grew in the gaps between states, so do images of piracy reflect diverse interests too. Exquemelin describes sadists, Captain Johnson prefers libertarians, romantic authors seemed to enjoy the mystery of the outsider, while $20^{\text {th }}$ century film moved from 
swashbuckling hero to comedy villain. Captain Jack adds the rock star swagger, and a metrosexually knowing smile. All these images are interesting enough, since they ask questions of identity, but the original context of the pirate also asks a question about the relation between the individual and the state, and the legitimacy of trade. It is perhaps no wonder that, in the third Pirates of the Caribbean film, Jack's enemy is the East India Company itself, one of the world's first global corporations, and with its own army and navy. These are issues that, in an era of international business and privatised war, have perhaps become even more urgent than ever. The fact that the Disney corporation makes so much money from Jack Sparrow isn't really an irony, but the culmination of four centuries work on turning boatloads of privateers into these global corporations. Jack Beeching, in his introduction to Exquemelin's violent utopian travelogue, captures a similar sentiment.

'Anarchistic, untrammelled, extravagant, sadistic, a crack shot and wildly courageous, the buccaneer is a gay dog amongst Protestant paladins - not only a fantasy figure for today's cautiously ethical businessman, but his exact historical progenitor.' (2000: 20)

\section{Acknowledgements}

Thanks to all those who have helped me with this paper by drawing attention to various pirate materials, and to Simon Lilley, Jeroen Veldman and the editor and referees of this journal for their comments.

\section{Bibliography}

Armstrong, S (2008) War Plc: The Rise of the New Corporate Mercenary. London: Faber \& Faber. 
Bruce, S (1999) 'Introduction'. In S Bruce (ed) Three Early Modern Utopias. Oxford: Oxford University Press.

Burg, B (1985) Sodomy and the Pirate Tradition. New York: New York University Press.

Burl, A (2006) Black Barty: Bartholomew Roberts and His Pirate Crew 1718-1723. Stroud, Gloucs: Sutton Publishing.

Burnett, J (2003) Dangerous Waters. New York: Plume.

Burroughs, W (1999) Word Virus: The William Burroughs Reader. (eds J Grauerholz and I Silverberg). London: Flamingo.

Chwastiak, M (2007) 'War Incorporated'. Paper presented at Critical Management Studies 5 conference, University of Manchester.

Cordingly, D (1999) Life Among the Pirates. London: Abacus.

Do or Die (1999) 'Pirate Utopias' Do or Die 8: 63-78. (www.ecoaction.org/dod/no8/pirate.html)

Earle, P (2004) The Pirate Wars. London: Methuen.

Exquemelin, A (2000) The Buccaneers of America. Mineola, NY: Dover Publications.

Hympendahl, K (2003) Pirates Aboard. Dobbs Ferry, NY: Sheridan House. 
Johnson, C (1998) A General History of the Robberies and Murders of the Most Notorious Pirates. London: Conway Maritime Press.

Lamborne Wilson, P (1995) Pirate Utopias. Brooklyn, NY: Autonomedia.

Land, C (2007) 'Flying the Black Flag' Management and Organizational History 2/2: 169192.

Langewiesche, W (2006) The Outlaw Sea. London: Granta.

Lapouge, G (2004) Pirates and Buccaneers. London: Hachette Illustrated.

Lewis, J (ed (2006) The Mammoth Book of Pirates. London: Robinson.

Linebaugh, P and Rediker, M (2000) The Many-Headed Hydra. Boston: Beacon Press.

Kontorovich, E (2004) ‘The Piracy Analogy' Harvard International Law Journal, 45/1: 183237.

Matthews, J (2006) Pirates. London: Carlton Books.

Osborne, L (1998) ‘A Pirate's Progress' Linguafranca, 8/2, March.

(http;//linguafranca.mirror.theinfo.org/9803/Osborne.html) 
Parish, J (1995) Pirates and Seafaring Swashbucklers on the Hollywood Screen. Jefferson, NC: McFarland \& Co.

Parker, M (2008) ‘Heroic Villains: The Badlands of Economy and Organization’ In M Kostera (ed) Organizational Epics and Sagas: Tales of Organizations. London: Palgrave, pp105-117.

Parker, M, Fournier, V and Reedy, P (2007) The Dictionary of Alternatives. London: Zed.

Rediker, M (1987) Between the Devil and the Deep Blue Sea. Cambridge: Cambridge University Press.

Rediker, M (2004) Villains of All Nations. London: Verso.

Richards. J (1977) Swordsmen of the Screen. London: Routledge and Kegan Paul.

Rogozinski, J (1997) Dictionary of Pirates. Ware, Herts: Wordsworth Editions.

Ruggerio, V (2000)'Daniel Defoe and Business Crime', in Crime and Markets: Essays in Anti-Criminology. Oxford: Oxford University Press.

Snelders, S (2005) The Devil's Anarchy. Brooklyn, NY: Autonomedia.

Stanley, J (ed) (1996) Bold in her Breeches. London: Pandora/HarperCollins. 
Surowiecki, J (2007) 'The Pirates Code', New Yorker Online, July $9^{\text {th }}$,

www.newyorker.com/online/2007/07/09/070709on_onlineonly_surowiecki, accessed $14^{\text {th }}$

July 2007.

Tennyson Jesse, F (1927/1981) Moonraker. London: Virago.

Woodard, C (2007) The Republic of Pirates. New York: Harcourt Brace Jovanovich.

\footnotetext{
${ }^{1}$ For more on metaphors of piracy in the context of intellectual property, see Land 2007.

${ }^{2}$ Though there is no agreement over the etymology of this 'Jolly Roger'. It could relate to a colloquialism for the devil, 'Old Roger'. It could be a corruption of Ali Raja, a Tamil pirate captain. Most likely it comes from Jolie Rouge, the bloody flag of combat. (Cordingly 1999: 142)

${ }^{3}$ For a fuller account of the Defoe authorship controversy, see Cordingly's introduction to Johnson 1998, or Burl 2006: 265-270. On Defoe's fascination with the boundaries between crime and the market, see Ruggerio 2000.

${ }^{4}$ In a strange piece of intertextuality, Exquemelin also makes reference to an 'Island of Pines' (2000: 128). This was the previous name for an island off the south west coast of Cuba, now called the 'Isla de la Juventud' (Isle of Youth). It has also been known as the Isle of Parrots, and 'Isla de Tesoros' (Treasure Island). The distinction between utopian writing, travel writing, the diary and fiction is unclear in many of these early texts. Similarly, there is often confusion over authorship. No-one knows who Exquemelin was, and Louis Le Golif's Memoirs of a Buccaneer, discovered in France at the end of the second world war, and though supposedly written in the 1690s may even be a forgery (Lewis 2006: 38). This book is cited by Do or Die (1999) as a source for homosexuality on Tortuga.

5 James Surowiecki (2007), has even proposed that contemporary management could learn from the link between forms of democracy which solve the problem of CEO self interest and that of employee motivation. He suggests, half joking, 'The Management Lessons of Captain Kidd'. Clearly Surowiecki knows little about Kidd's ignominious career, and seemingly nothing at all about the many attempts at worker self-management (Parker et al 2007). ${ }^{6}$ Which became Libertatia in the 1952 film Against All Flags, and was destroyed by Errol Flynn in order to keep the ships of the East India Company safe.
} 